\title{
Antioxidant and cytotoxic activities of sulfated polysaccharides from five different edible seaweeds
}

\author{
K. Arunkumar ${ }^{1} \cdot$ Rathinam Raja $^{2}$ (D) V. B. Sameer Kumar ${ }^{3} \cdot$ Ashna Joseph $^{1} \cdot$ T. Shilpa ${ }^{1} \cdot$ Isabel S. Carvalho $^{2}$
}

Received: 19 June 2020 / Accepted: 11 September 2020 / Published online: 17 September 2020

(c) Springer Science+Business Media, LLC, part of Springer Nature 2020

\begin{abstract}
In recent times, there has been a growing interest in the exploration of antioxidants and global trend toward the usage of seaweeds in the food industries. The low molecular weight up to $14 \mathrm{kDa}$ sulfated polysaccharides of seaweeds (Portieria hornemannii, Spyridia hypnoides, Asparagopsis taxiformis, Centroceras clavulatum and Padina pavonica) were evaluated for in vitro antioxidant activities and cytotoxic assay using HeLa cell line and also characterized by FTIR. The high yield (7.74\% alga dry wt.) of sulfated polysaccharide was observed in P. hornemannii followed by S. hypnoides (0.69\%), C. clavulaum $(0.55 \%)$ and A. taxiformis $(0.17 \%)$. In the brown seaweed P. pavonica, the sulfated polysaccharide yield was $2.07 \%$. High amount of sulfate was recorded in the polysaccharide of A. taxiformis followed by C. clavulaum, P. pavonica, S. hypnoides and $P$. hornemannii as indicative for bioactivity. The FTIR spectroscopic analysis supports the sulfated polysaccharides of $S$. hypnoides, $C$. clavulatum and A. taxiformis are similar to agar polymer whereas the spectral characteristics of $P$. hornemannii have similarities to carrageenan. The higher DPPH activity and reducing power were recorded in the polysaccharide of brown seaweed P. pavonica than the red seaweeds as follows: DPPH activities: $S$. hypnoides $>A$. taxiformis $>$ C. clavulatum $>$ P. hornimanii; Reducing power: A. taxiformis $>$. hornimanii $>S$. hypnoides $>C$. clavulatum. The polysaccharide fractions contain up to $14 \mathrm{kDa}$ from red seaweeds $P$. hornemannii and $S$. hypnoides followed by brown seaweed $P$. pavonica exhibit cytotoxic activity in HeLa cancer cell line (and are similar to structural properties of carrageenan extracted from $P$. hornemannii). The low molecular weight agar like polymer of $S$. hypnoides and alginate like brown seaweed P. pavonica showing better in vitro antioxidant activities that are capable of exhibiting cytotoxicity against HeLa cell line can be taken up further in-depth investigation for nutraceutical study.
\end{abstract}

Keywords Seaweeds $\cdot$ Sulfated polysaccharides $\cdot$ Antioxidants $\cdot$ Cytotoxic assay $\cdot$ HeLa cell lines

\section{Introduction}

Marine macroalgae (seaweeds) are the only resource for industrially important polymers such as agar and carrageenan from red seaweeds; alginate, fucoidan and laminarin from brown seaweeds. These polymers are extracted

Rathinam Raja

rraja307@gmail.com

1 Department of Plant Science, Central University of Kerala, Periye, Kerala 671 320, India

2 MED-Mediterranean Institute for Agriculture, Environment and Development, Food Science Laboratory, FCT, University of Algarve, Building 8, Gambelas, 8005-139 Faro, Portugal

3 Department of Biochemistry and Molecular Biology, Central University of Kerala, Periye, Kerala 671 320, India only from few seaweed species that meet certain industrial applications. This seaweed sulfated polysaccharides possess a variety of biological activities and immunomodulatory activities to mitigate associated negative effects including inflammation [1]. These polysaccharides have been used in food industries as gelling agents, thickening, and stable excipients for control release of drugs [2]. Recently, in a test of antiviral effectiveness against the virus which causes COVID-19, an extract from edible seaweeds substantially outperformed remdesivir, the current standard antiviral agent used to combat the disease. Further Heparin, a common blood thinner, and a heparin variant stripped of its anticoagulant properties, performed on par with remdesivir in inhibiting SARS-CoV-2 infection in mammalian cells [3]. Beside, this seaweed hydrocolloids have great economic importance because of their various bioactive (anticoagulant, antiviral, anticancer, antioxidant, antitumor, 
immunomodulating, antihyperlipidemic and antihepatotoxic activities) and unique rheological properties, hence they are being widely used in the pharmaceutical and biomedical sectors [4-6]. The structural features like the composition of monomers, sulfate level and its position in the sugar moiety, chain length, molecular weight etc. of the polymer make them ideal materials for various biomedical applications [7, 8]. Cholesterol and lipid-controlling properties of carrageenan have been demonstrated in a clinical trial and found significant reduction in the serum cholesterol and triglyceride levels [9]. Carrageenan is well known in controlling the inflammation and a complete review on carrageenan biological activities was reported [10, 11]. Recently, Zhong et al. [8] reviewed the cytotoxic and antioxidant activity in various seaweeds polysaccharides.

Among five seaweeds, the red Portieria hornemannii, Spyridia hypnoides, Asparagopsis taxiformis and Centroceras clavulatum; and brown seaweed Padina pavonica were taken up, a monoterpene possessing cytotoxicity against a diverse panel of human tumor cell line was isolated from the red alga Portieria hornemannii [12]. The antioxidant and in vitro cytotoxic activity of extracts prepared using methanol, chloroform, petroleum ether and ethyl acetate from red alga Asparagopsis taxiformis were demonstrated [13]. In another study, ethanol extract significantly exhibiting antibacterial activity against fish pathogenic bacteria was found [14]. Ethanolic extract of brown alga, Padina pavonica having antimicrobial, antioxidant, and anticancer activities was proved [15]. Padina pavonica extract contain phenolic, flavonoid and tannin which exhibits antioxidant activity [16] whereas there is no report on Spyridia hypnoides and Centroceras clavulatum. Further, in vitro antioxidant activity and cytotoxic assay using cancer cell-line from these five algae sulfated polysaccharides are significant. Because taping the potential of these seaweeds which are not exploited for polysaccharides of industrial quality and by considering its food value, they can be utilized for the source of compounds of biomedical and nutraceutical values. Hence, in the present study, results of sulfated polysaccharides extracted from these five seaweeds were evaluated also for antioxidant and cytotoxic properties.

\section{Materials and methods}

\section{Collection of seaweeds}

The fresh and healthy specimens of red seaweeds about $3 \mathrm{~kg}$ of Portieria hornemannii (Lyngbye) P.C. Silva, Spyridia hypnoides (Bory) Papenfuss, Asparagopsis taxiformis (Delile)
Trevisan and Centroceras clavulatum (C. Agardh) Montagne; and brown seaweed Padina pavonica (Linnaeus) Thivy occurring along the Coast of Pamban $\left(9.2798^{\circ} \mathrm{N}, 79.2291^{\circ} \mathrm{E}\right)$, Gulf of Mannar, Tamil Nadu, India were collected during the month of September 2018.

\section{Extraction and fractionation of polysaccharides}

The extraction procedure of Distantina et al. [17] was followed with minor modifications. The collected five seaweeds were cleaned with fresh water to remove epiphytes and sand particles. The samples were shade dried under air in dark for 5 days. Thirty gram of dried seaweeds was soaked in $250 \mathrm{~mL}$ of $0.3 \mathrm{~N}$ $\mathrm{KOH}$ solutions for $12 \mathrm{~h}$ and then heated at $60^{\circ} \mathrm{C}$ for $30 \mathrm{~min}$. The alkaline digested sample was washed thrice in $250 \mathrm{~mL}$ of tap water and then $0.1 \mathrm{~N} \mathrm{HCl}$ was added into digested sample until the $\mathrm{pH}$ was neutral (7.0). Then distilled water was added to sample to reach 1:50 ratio (30:1500 w/v) and extracted by heating at $80{ }^{\circ} \mathrm{C}$ for $1 \mathrm{~h}$. The hot water extract was filtrated through muslin cloth followed by Whatman No. 1 filter paper and cooled. The crude polysaccharide in the filtered extract was precipitated by adding cold $\left(4{ }^{\circ} \mathrm{C}\right) 90 \%$ ethanol in $1: 150$ ratio (30:4500 sample: $90 \%$ ethanol $\mathrm{w} / \mathrm{v}$ ). The precipitate was collected and stored at $4{ }^{\circ} \mathrm{C}$ over night and thawed further, the crude polysaccharide was separated by centrifugation at $704 \times g$ for $5 \mathrm{~min}$ to remove cell debris. Then the supernatant was collected and again centrifuged at $7826 \times \mathrm{g}$ for $10 \mathrm{~min}$ to obtain pellets of crude polysaccharides which were stored at $4{ }^{\circ} \mathrm{C}$. These pellets were dialyzed using dialysis tubing of $14 \mathrm{kDa}$ (Sigma Aldrich D9652) molecular weight cut off against two volumes of distilled water for $24 \mathrm{~h}$ at room temperature then freeze-dried and weighed (Fig. 1. Flow chart).

\section{Estimation of sulfate in fractionated polysaccharides}

The total sulfate [18] content of dialyzed polysaccharides were estimated.

\section{Characterization of polysaccharides by FTIR spectra}

The extracted polysaccharides were characterized by FTIR spectroscopy (Perkin-Elmer Version 10.5.1 spectrometer, Boston, USA). The polysaccharide $(5 \mathrm{mg}$ ) of each seaweeds were ground with spectroscopic grade potassium bromide $(\mathrm{KBr})$ powder and pressed into $1 \mathrm{~mm}$ pellet for FTIR measurement in the wavelength that ranges from 400 to $4000 \mathrm{~cm}^{-1}$ [19]. The FTIR spectrum was finalized on the basis of spectral consistency recorded from triplicate $\mathrm{KBr}$ powder samples from each seaweed. 
Fig. 1 Flow chart for the extraction and fractionation of seaweed sulfated polysaccharides
Extraction and fractionation of seaweed sulfated polysaccharides

Fresh seaweeds $(3 \mathrm{Kg})$

Cleaned/washed in fresh water to remove

epiphytes/sand particles/ shade dried

Shade dried $(30 \mathrm{~g})$ soaked in $250 \mathrm{~mL}$ of $0.3 \mathrm{~N} \mathrm{KOH}$ for $12 \mathrm{hrs}$ then heating at $60^{\circ} \mathrm{C}$ for $30 \mathrm{mins}$

Washed thrice in $250 \mathrm{~mL}$ of tap

$\downarrow$ water

$0.1 \mathrm{~N} \mathrm{HCl}$ was added into digested sample until the $\mathrm{pH} 7.0$

Dis. $\mathrm{H}_{2} \mathrm{O} \quad(1: 50$ ratio $\mathrm{w} / \mathrm{v})$ and extracted

$\downarrow$ polysaccharides by heating at $80^{\circ} \mathrm{C}$ for $1 \mathrm{hr}$

Filtered through muslin cloth then Whatman No. 1 filter paper

Crude polysaccharide in the filtrate precipitated by adding cold $\left(4^{\circ} \mathrm{C}\right) 90 \%$ ethanol in 1: 150 ratio (30: 4500 : sample:

$\downarrow 90 \%$ ethanol $\mathrm{w} / \mathrm{v}$ )

Polysaccharide separated by centrifugation at $704 \times \mathrm{g}$ for 5 mins to remove cell debris pellets

Supernatant again centrifuged at $7826 \times \mathrm{g}$ for 10

mins, pellets dialyzed ( $14 \mathrm{KDa}$ ) for $24 \mathrm{hrs}$ at room

temperature with 2 volumes dis. $\mathrm{H}_{2} \mathrm{O}$

Polysaccharide collected in the dialysis bag

\section{In vitro antioxidant activities of the polysaccharide}

\section{DPPH radical scavenging activity}

The scavenging effects of polysaccharide were determined using ascorbic acid as a positive control [20]. For the assay, $2 \mathrm{~mL}$ of $0.16 \mathrm{mM}$ DPPH in methanol was added into the test tube containing $2 \mathrm{~mL}$ aliquot of test sample at various concentrations $(0.1,0.5$ and $1 \mathrm{~mL}$ from stock of $1 \mathrm{mg} \mathrm{mL}{ }^{-1}$ ). The mixture was vortexed for $1 \mathrm{~min}$ and kept at room temperature for $30 \mathrm{~min}$ in the dark. The absorbance was measured at $517 \mathrm{~nm}$ in a UV-visible spectrophotometer (Shimadzu UV-2600). The capacity to scavenge the DPPH radical was calculated by the following equation:

Scavenging effect (\%)

$$
=\left[1-\left(\mathrm{A}_{\text {sample }}-\mathrm{A}_{\text {sample blank }}\right) / \mathrm{A}_{\text {control }}\right] \times 100
$$

where, $\mathrm{A}_{\text {control }}$ is the absorbance of the control (DPPH solution without sample); A sample is the absorbance of the test sample (DPPH solution plus test sample); $\mathrm{A}_{\text {sample blank }}$ is the absorbance of the sample (sample without DPPH solution).

\section{Reducing power}

The reducing power of fractioned polysaccharide was determined by following the method described by Yen and Chen [20]. One $\mathrm{mL}$ of polysaccharide solution in various concentrations $\left(0.1-1 \mathrm{mg} \mathrm{mL}^{-1}\right)$ was mixed with $2.5 \mathrm{~mL}$ of phosphate buffer $(0.2 \mathrm{M}, \mathrm{pH} 6.6)$ and potassium ferricyanide $(2.5 \mathrm{~mL}, 1 \%)$. The mixture was incubated at $50{ }^{\circ} \mathrm{C}$ for $20 \mathrm{~min}$ and rapidly cooled. A $2.5 \mathrm{~mL}$ of trichloroacetic acid (10\%) was added into the mixture and centrifuged at $704 \times g$ for $10 \mathrm{~min}$. The upper layer of the solution $(2.5 \mathrm{~mL})$ was mixed with distilled water $(2.5 \mathrm{~mL})$ and $0.5 \mathrm{~mL} \mathrm{FeC1}_{3}$ $(0.1 \%)$ was measured at $700 \mathrm{~nm}$ absorbance. An increased absorbance of the reaction mixture indicated the increased reducing power activity. The ascorbic acid $\left(1 \mathrm{mg} \mathrm{mL}^{-1}\right)$ was used as a control.

\section{MTT assay}

The cytotoxic activities of the five algal polysaccharides were examined using colorimetric 3-(4,5-dimethylthiazolyl2-yl)-2,5-diphenyltetrazolium bromide, a tetrazole (MTT) assay [21]. Formation of purple formazan by reduction takes place only when mitochondrial reductase enzymes are active, and therefore conversion can be directly related to the number of viable (living) cells. The effectiveness of this agent in causing cell death can be deduced, through the production of dose-response curve. The resulting purple solution is spectrophotometrically measured.

HeLa cells cultured in a complete DMEM (10\% FBS, $1 \%$ antibiotic-antimycotic solution) were seeded 5000 cells per well in 96-well plate and incubated in $5 \% \mathrm{CO}_{2}$ for $24 \mathrm{~h}$. After attachment of cells, $100 \mu \mathrm{L}$ of polysaccharide of increasing 
dilutions (starting from $1 \mathrm{mg} \mathrm{mL}^{-1}$ to $0.0019 \mathrm{mg} \mathrm{mL}^{-1}$ ) were added to the wells and incubated for $24 \mathrm{~h}$. Blank wells containing DMEM alone and control wells with cells and no added drug were maintained for each plate. MTT reagent at $0.5 \mathrm{mg} \mathrm{mL}^{-1}$ was added followed by incubation for $3 \mathrm{~h}$. Formazon crystals were dissolved in DMSO and the absorbance was read at $570 \mathrm{~nm}$ with a reference wavelength of 630 .

\section{Statistical analysis}

The differences in the biological activities among the polysaccharides were tested for significance $(p<0.05)$ by oneway analysis of variance (ANOVA) by the Tukey post hoc comparison test using SPSS14.0.

\section{Results and discussion}

The seaweed polysaccharides were extracted from Portieria hornemannii, Spyridia hypnoides, Asparagopsis taxiformis, Centroceras clavulatum and Padina pavonica and their sulfate content was analyzed (Table 1). Agar and carrageenan are present in red seaweeds and glugan is found in green seaweeds whereas brown seaweeds contain alginate and fucoidan [22]. The red seaweed species such as Gelidium, Gracilaria, Gelidiella, Ahnfeltia, Pterocladia, Aconthopeltis, and Annfeltia are the major source for agar collectively called agarophytes [22] and the agar content is varied depending on the species for example, 53\% in Gracilaria sp. whereas in Gelidium 44\% [23]. These seaweed polysaccharides are commercially utilized worldwide in the processed foods, cosmetics, pharmaceutical products and medicine as gelling and stabilizing agents [24].

Carrageenans, an another major cell wall polysaccharides extracted from certain species of red seaweeds (Rhodophyceae) belong to the family members of Solieriaceae, Rhabdoniaceae, Hypneaceae, Phyllophoraceae, Gigartinaceae, Furcellariaceae and Rhodophyllidaceae [22]. This group of algae constitutes carrageenan up to $75 \%$ (dry wt.) in Kappaphycus with 15 to $40 \%$ of ester-sulfate content [25] and these species polymers are being used in various food industries as texturing and gelling agents [26, 27]. It also exhibits

Table 1 Yield and sulfate content of seaweed polysaccharides

\begin{tabular}{lllc}
\hline S.No & Seaweed & $\begin{array}{l}\text { Total yield }(\% \\
\text { alga dry wt.) }\end{array}$ & Sulfate content $(\mu \mathrm{g} / \mathrm{mg})$ \\
\hline 1 & P. hornemannii & 7.74 & $1.08 \pm 0.38$ \\
2 & S. hypnoides & 0.69 & $2.31 \pm 0.47$ \\
3 & C. clavulaum & 0.55 & $17.12 \pm 1.37$ \\
4 & A. taxiformis & 0.18 & $48.51 \pm 4.83$ \\
5 & P. pavonica & 2.07 & $3.18 \pm 0.71$ \\
\hline
\end{tabular}

various biological and biomedical properties $[4,6]$. The brown seaweeds (Phaeophyceae) contain alginate up to $40 \%$ in some species, example Ascophylum nodosum 22-30\%, Laminaria digitata 25-44\%, Sargassum sp. 17-45\% [28, 29]. Agar extracted in red seaweeds in the molecular weight range of $100-30,000 \mathrm{kDa}[30]$. Among the different fraction of polysaccharides $(3.2,10.5,29.0$, and $48.8 \mathrm{kDa})$ isolated from red seaweed Pyropia yezoensis, $3.2 \mathrm{kDa}$ found as effective against stress protection [31]. The yield of carrageenan varies depending on species and up to $70 \%$ (dry basis) was recorded from some species such as Betaphycus gelatinum and Kappaphycus alvarezii. Other species like Eucheuma denticulatum and Chondrus crispus had $30 \%$ yields. Sulfate content of carrageenans varied depends on the types (20\% in кappa, $33 \%$ in ioda and $41 \%$ in $\lambda$ ) [32]. The molecular weight of commercially values carrageen in the range of 100 to $800 \mathrm{kDa}$ was recorded [25] and low molecule weights possess more bioactivity properties [33]. Sulfated galactan of $16 \mathrm{kDa}$ showing anticoagulant and antioxidant activities was purified from red Spyridia hypnoides [34]. Sulfated polysaccharide of 60 to $500 \mathrm{kDa}$ isolated from Red seaweed Asparagopsis taxiformis exhibit anticoagulant activity [35].

In this study, polysaccharide from five seaweeds $(P$. hornemannii, $S$. hypnoides, A. taxiformis, $C$. clavulatum and $P$. pavonica) up to $14 \mathrm{kDa}$ was isolated by considering the significance of high bioactivity recorded in low molecular weight polysaccharides [36]. Whereas the alginate polymer of brown seaweeds in the range of $300-1000 \mathrm{kDa}$ is commercial valuable $[37,38]$ but low molecule weight alginate polymers have potential bioactive properties [39]. Among the four red seaweeds, highest yield of $7.74 \%$ dry wt. of sulfated polysaccharide was extracted from $P$. hornemannii followed by $S$. hypnoides $(0.69 \%), C$. clavulaum $(0.55 \%)$ and $A$. taxiformis $(0.176 \%)$. Whereas the yield of sulfated polysaccharide extracted from the brown seaweed, Padina pavonica was $2.07 \%$ dry wt. (Table 1 ). Comparing the polysaccharides of terrestrial plant origin, seaweed polysaccharides constitute unique monomers like galactose, mannose, fucose, xylose etc. with varying degree of sulfation in their sugar residues [40] that influence the structure and biological properties of polymer isolated from each seaweed species [41]. This sulfate group of sugar moieties is found responsible for exhibiting anionic charge to the polymers [27, 39, 40]. Antibacterial and antiviral activity of anionic seaweed sulfated polysaccharides exhibit by binding the positively charged glycoprotein virus envelope and bacteria cell surface thereby integrating with virus or bacteria thus it prevent the pathogens entry into host cells [42-44]. Positive charge glycoprotein receptor of bacteria cell surface bind sulfate polysaccharides thereby inhibiting the bacteria [44]. So, high sulfate content in seaweed polysaccharides proportionally display more bioactivity $[45,46]$. This study results showing high amount of sulfate in the polysaccharides of $A$. 
taxiformis $\left(48.51 \pm 4.83 \mu \mathrm{mg}^{-1}\right)$ followed by $C$. clavulaum, P. pavonica, S. hypnoides and P. hornemannii (Table 1) indicate the potential of these polysaccharides for biological activity.

\section{FTIR spectroscopy characterization of polysaccharides}

\section{Structure of agar, carageenan and alginate}

Agar and carrageenan extracted from Rhodophyceae (red seaweeds), the latter is highly sulfated ones. Thus, it constitutes repeating disaccharide units of 3-linked $\beta$-D-galactose (G-units) and 4-linked $\alpha$-galactose (D-units) or 3,6-anhydro$\alpha$-galactose (AnGal-units) whereas agar is less sulfated polymer composed of agarose, agaropectin, fibre, protein and ash. The agaropectin of agar is a charged sulfated non-gelling polymer constitutes D-glucuronic acid, and small amounts of pyruvic acid. The gelling part of the agar, agarose is a neutral polymer with molecular weight of $120 \mathrm{kDa}$ free of sulfate constitute repeating unit of agarobiose. It is a disaccharide made by $\beta$-1,3-linked- D-galactose and $\alpha$-1,4-linked 3,6-anhydro-L-galactose [47] that is constituted by repeating units of D-galactose and L-galactose [48, 49]. The specific band at $890 \mathrm{~cm}^{-1}$ for agar attributed to anomeric $\mathrm{C}-\mathrm{H}$ of $\beta$-galactose residues generally absent in carrageenan [50]. At least fifteen different types of carrageenan categorized on the basis of structural characteristics, they are: sulfation patterns and presence or absence of AnGal on D-units are reported from various red seaweed species and most prevalent are ioda, lamda and kappa [51] with molecular weight in the range of 100 to $800 \mathrm{kDa}$ was recorded [25]. The cell wall of brown seaweeds mainly contain alginate polymer which constitute the blocks of $\beta$-1,4-linked D-mannuronic acid and blocks of $\alpha-1,4-1$ inked L-guluronic acid or blocks of D-mannuronic acid alternatively by L-guluronic acid [52].

\section{Red seaweed polysaccharides}

The FTIR spectroscopy remains a best tool to characterize the seaweed polysaccharides by identifying their functional groups [53]. The broad band between 3500 and $3200 \mathrm{~cm}^{-1}$ due to stretching vibrations of $\mathrm{OH}$ group is recorded in the FTIR spectra of all seaweed polysaccharides and standard spectra of agar, carrageenan and alginate (Figs. 2 and 3). The FTIR spectral characters of polysaccharides of red seaweeds Portierea hornemanii, Spiridia hypnoides, A. taxiformis and C. clavulatum were compared with both agar and carrageenan standards (Fig. 2). A peak at $930 \mathrm{~cm}^{-1}$ shows the presence of $\mathrm{C}-\mathrm{O}-\mathrm{C}$ of glycosidic bond for 3,6-anhydroL-galactose of agar and 3,6-anhydro-D-galactose of carrageenan is found in the spectra of both standards (agar and carrageenan), Spyridia hypnoides, A. taxiformis and $C$. clavulatum $[53,54]$. A band at $1650 \mathrm{~cm}^{-1}$ for carbonyl group of a carboxylic acid; a peak at $1375 \mathrm{~cm}^{-1}$ and a broad band in between 1210 and $1280 \mathrm{~cm}^{-1}$ indicate the presence of sulfate esters and a peak at $1140 \mathrm{~cm}^{-1}$ for $\mathrm{C}-\mathrm{O}$ glycosidic bond are recorded in all red seaweed polysaccharide samples as well as both agar and carrageenan standards [Fig. 2; 53, 54].

A peak at $840 \mathrm{~cm}^{-1}$ show the presence of galactose sulfated at $\mathrm{C} 4$ is found in the spectra of carrageeenan standard and polysaccharides of Spyridia hypnoides and A. taxiformis (Fig. 2b). Agar differs from carrageenan by having L-configuration for the 4-linked galactose residue; nevertheless, they have some structural similarities with carrageenan. Peaks at $770 \mathrm{~cm}^{-1}$ and $740 \mathrm{~cm}^{-1}$ for pyranose ring are recorded in all the spectra (Figs. 2ab, 4). Agar specific peak at $890 \mathrm{~cm}^{-1}$ due to anomeric $\mathrm{CH}$ in the $\beta$-galactose residues and a band at $930 \mathrm{~cm}^{-1}$ correspond to 3,6-anhydro-L-galactose recorded in the spectra of agar standard, Spyridia hypnoides and Centroceras clavulatum belong to the order Ceramiales and Asparagopsis taxiformis of the Order Florideophyceae confirmed the presence of polysaccharides in agar forms $[34,50]$ and the spectral characteristics of $P$. hornemannii of order Gigartinales shows more spectral similarities with the carrageenan standard. The FTIR spectral characteristics found the presence of agar form of low molecular weight up to $14 \mathrm{kDa}$ polysaccharides in $S$. hypnoides, $C$. clavulatum and $A$. taxiformis and carrageenan form in $P$. hornemannii, among the four red seaweeds.

\section{Brown seaweed polysaccharides}

The FTIR spectral characteristics of polysaccharide of brown seaweed, Padina pavonica show spectral similarities with alginate standard (Fig. 3). Peaks at $3250 \mathrm{~cm}^{-1}$ assigned for OH groups; $1620 \mathrm{~cm}^{-1}$ for $\mathrm{S}=\mathrm{O} ; 1420 \mathrm{~cm}^{-1}$ for $\mathrm{C}-\mathrm{O}$ and $1025 \mathrm{C}-\mathrm{O}-\mathrm{C}$ groups are recorded from the spectra of both alginate standard and sample [55]. Peaks at $1290 \mathrm{~cm}^{-1}$ for $\mathrm{M} / \mathrm{G}$ block (Mannose/Galactose) and at $808 \mathrm{~cm}^{-1}$ assigned to $\mathrm{M}$ block are recorded from the spectra of both alginate standard and sample $[7,56]$. The anomeric region of fingerprint $\left(950-750 \mathrm{~cm}^{-1}\right)$ showed three characteristic absorption bands in alginate standard and sample. A band at $950 \mathrm{~cm}^{-1}$ is assigned to the $\mathrm{C}-\mathrm{O}$ stretching vibration of uronic acid residues, the one at $880 \mathrm{~cm}^{-1}$ is assigned to the $\mathrm{C} 1-\mathrm{H}$ deformation vibration of $\beta$-mannuronic acid residues and the band at $808 \mathrm{~cm}^{-1}$ is characteristic of mannuronic acid residues [57]. From this spectral data the extracted polysaccharide of Padina pavonica shows similar characteristics of alginate polymer. 
Fig. 2 FTIR spectra of sulphated polysaccharide of red seaweeds (Portieria hornemannii-Ph, Spyridia hypnoides-Sh, Asparagopsis taxiformis-At, Centroceras clavulatum-Cc and Padina pavonica-Pp) by comparing agar and carrageenan standards
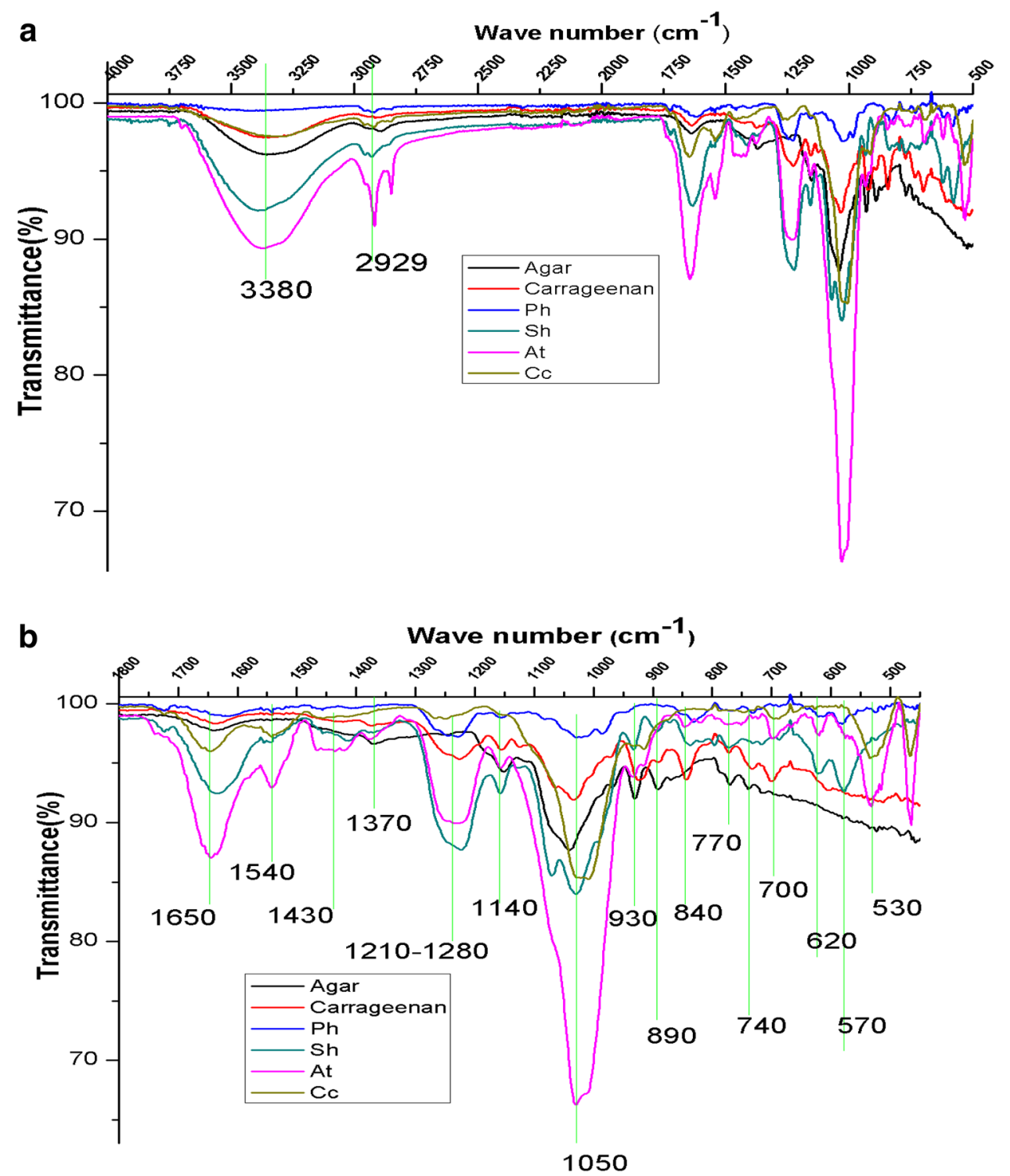

\section{Antioxidant activities}

In vitro antioxidant examinations are used to measure the degree of protection against free radicals [58]. Seaweed polysaccharides having antioxidant properties are the promising source for manufacture of food products and pharmaceuticals [58]. The molecular weight, type of monomer residues, degree of sulfation and sulfate position significantly influence their antioxidant activity of seaweed polysaccharides [8]. In this study, among the in vitro antioxidant activities, DPPH hydroxyl radical scavenging and reducing power of the sulfated polysaccharides were measured.

\section{DPPH assay}

The free radical scavenging activities of different sulfated polysaccharides assessed by DPPH assay based on the hydrogen ion donating ability of the polysaccharide are presented (Fig. 4). DPPH is a stable free radical appears in purple color in methanol/ethanol turns colorless by reduction in the presence of hydrogen donating antioxidants [59]. The DPPH, a stable free radical shows maximum absorbance at $517 \mathrm{~nm}$ in methanol. When DPPH encounters a proton donating substance like antioxidant, radical would be scavenged and the absorbance reduced. For every sulfated polysaccharide tested, there was a concentration dependent increase in scavenging activity where $1 \mathrm{mg} \mathrm{mL} \mathrm{L}^{-1}$ polysaccharide of $P$. pavonica exhibited an increase in DPPH free radical scavenging activity up to $63 \%$. Khaled et al. [60] explained that the ethyl acetate fraction of the algae Padina pavonica showed the highest antioxidant activity (42.5\%); those activities may be due to phenolic compounds present in significant amounts in this fraction (8.98 GAE/g). In another study, Nouf et al. 
Fig. 3 FTIR spectrum of sulfated polysaccharide of brown seaweed Padina pavonica $(\mathrm{Pp})$ by comparing alginate standard

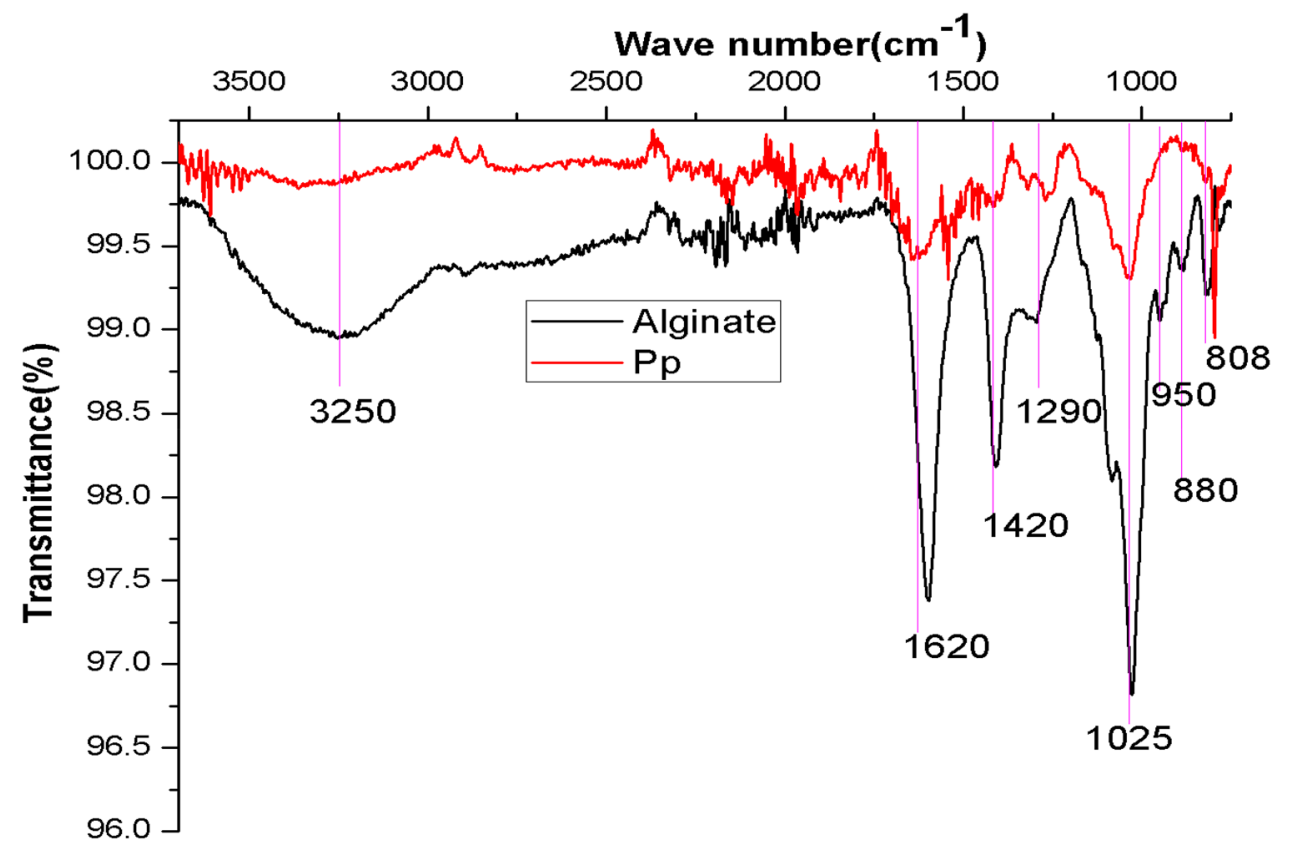

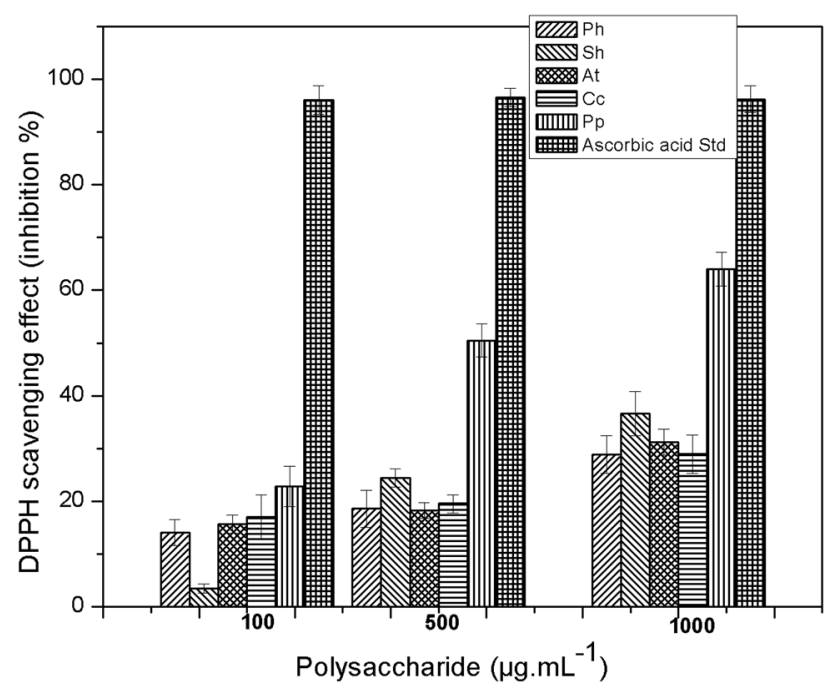

Fig. 4 DPPH free radical scavenging activity of sulfated polysaccharides (Portieria hornemannii-Ph, Spyridia hypnoides-Sh, Asparagopsis taxiformis-At, Centroceras clavulatum-Cc and Padina pavonica$\mathrm{Pp})$. Error bars indicate replicates standard deviation of each analysis

[61] described the extracts of Padina pavonica showed a concentration-dependent manner with maximum scavenging activity of $77.6 \%, \mathrm{IC}_{50}=5.59 \mu \mathrm{g} / \mathrm{mL}$. Among the red seaweeds, high DPPH activity was recorded by polysaccharide $\left(1 \mathrm{mg} \mathrm{mL}^{-1}\right)$ of Spyridia hypnoides followed by A. taxiformis (31\%) and C. clavulatum (28\%) compared to ascorbic acid as standard (96\%). Results from previous studies [62] are in accordance with the present study that polysaccharides of $P$. pavonica followed by red seaweeds
Spyridia hypnoides, A. taxiformis, C. clavulatum and $P$. hornimanii exhibit antioxidant power in their capacity to scavenge the DPPH radical and reduce ferric $\mathrm{Fe}^{3+}$ ions to $\mathrm{Fe}^{2+}$ by decreasing order.

\section{Reducing power assay}

The presence of antioxidant compounds with reducing ability exerts antioxidant activity by breaking the free radical chain or by donating a hydrogen atom. By reducing power assay, the ability of the polysaccharides capable of reducing $\mathrm{Fe}^{3+}$ to $\mathrm{Fe}^{2+}$ measured was recorded based on the increasing absorbance (Fig. 5). From the measurements of the reductive ability of the polysaccharides, the reducing power of all the five sulfated polysaccharides increased with increasing concentration although not as much as ascorbic acid exhibited. As reported by Jinzhe et al. [63], polysaccharide of $P$. pavonica had the greatest reducing power closely followed by red seaweeds $A$. taxiformis then P. hornimanii, Spyridia hypnoides and $C$. clavulatum implicated on the basis of sulfate content and monosugar constituents [64]. The Ferric reducing antioxidant power (FRAP) of P.pavonica reveals a higher antioxidant activity with IC50 $=0.4 \mathrm{mg} \mathrm{mL}^{-1}$ [65]. El-Shazoly and Fawzy [66] described that the ethyl alcohol extract of Padina pavonica showed significant activity (339.92 $\mathrm{mg} \mathrm{g}^{-1}$ dry wt.).

\section{In vitro cytotoxic assay using HeLa cell-line}

The five sulfated polysaccharides were assayed for the cytotoxic effect in HeLa cell line at different concentrations from $0.0019 \mathrm{mg} \mathrm{mL}^{-1}$ to $1 \mathrm{mg} \mathrm{mL}^{-1}$. The effect has measured 


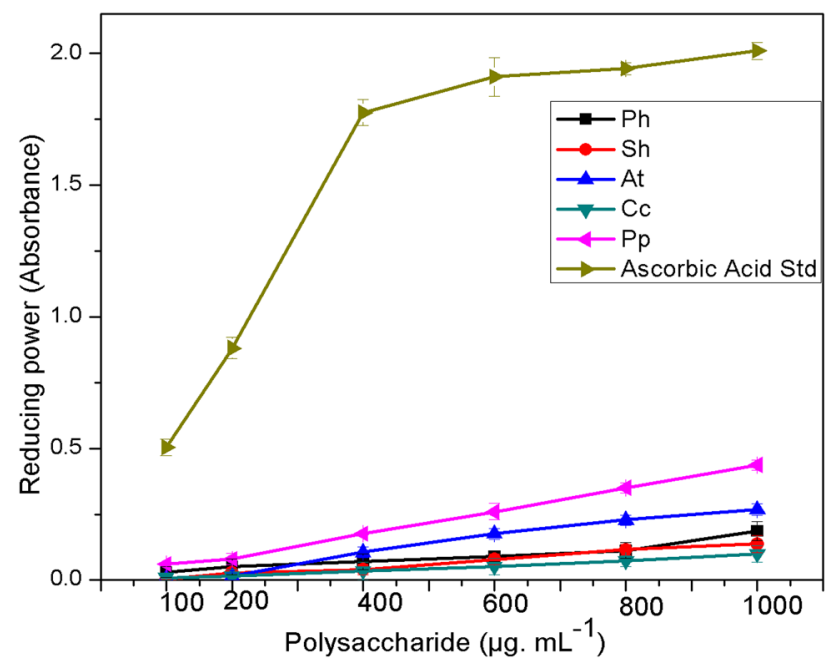

Fig. 5 Reducing power assay of sulfated polysaccharides (Portieria hornemannii-Ph, Spyridia hypnoides-Sh, Asparagopsis taxiformisAt, Centroceras clavulatum-Cc and Padina pavonica-Pp). Error bars indicate replicates standard deviation of each analysis

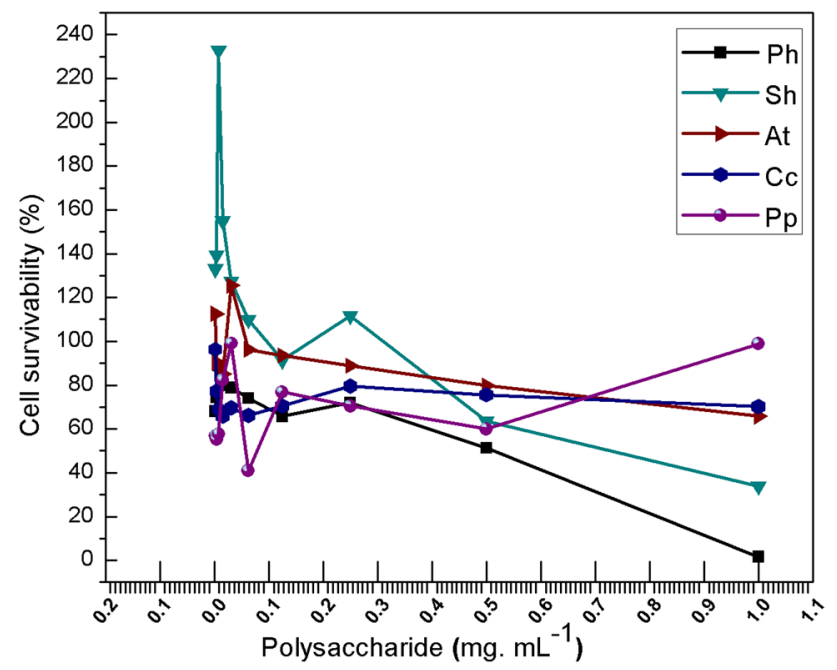

Fig. 6 Cell survivability of sulfated polysaccharides (Portieria hornemannii-Ph, Spyridia hypnoides-Sh, Asparagopsis taxiformis-At, Centroceras clavulatum-Cc and Padina pavonica-Pp) tested by MTT Assay using HeLa cell line

based on the cell survivability percent (Fig. 6) and $\mathrm{IC}_{50}$ values. Figure 6 evidently shows the concentration of polysaccharide increases the cell survivability decreases by the red seaweeds $P$. hornemannii and S. hypnoides. Ktari and Guyot [67] evaluated the cytotoxic activity of dichloromethane extract of Padina pavonica against KB cells and the results showed significant activity (IC50 $10 \mu \mathrm{g} \mathrm{mL}^{-1}$ ). The antitumor activity of Padina pavonica against breast cancer cells (MCF-7) and several strains of prostate cancer (DU$145, \mathrm{LNCaP}$ and PC3) by in vitro cytotoxicity assay with methanolic extract found that $P$. pavonica has more toxicity against cell strains tested according to Taskin et al. [68]. The cell survivability was decreased by low concentrations of $P$. pavonica polysaccharide but at high concentrations it promotes the cell survivability (Fig. 6) since the IC50 value was, 1.059 .

Indeed polysaccharides of $P$. hornemannii and S. hypnoides showed cytotoxic effects at higher concentrations but at low concentrations promote cell growth hence, IC50 values recorded were 0.428 and 0.755 , respectively (Fig. 7). Instead IC50 values for polysaccharides of $C$. clavulatum and A. taxiformis were 1.27 and 3.27, respectively indicate these polysaccharides have nutracetical values. This investigation results suggest that crude polysaccharides at high dose of red seaweeds $P$. hornemannii and S. hypnoides and at low dose of brown seaweed $P$. pavonica exhibit cytotoxic activity in HeLa cancer cell line whereas polysaccharides of C. clavulatum and A. taxiformis have nutraceutical values.

\section{Conclusion}

The sulfate recorded in the polysaccharide of A. taxiformis was higher followed by C. clavulaum, P. pavonica, S. hypnoides and $P$. hornemannii. The FTIR spectroscopy characteristics support that this low molecular weight sulfated polysaccharide fractions up to $14 \mathrm{kDa}$ extracted from $S$. hypnoides, C. clavulatum and A. taxiformi were similar to agar polymer whereas $P$. hornemannii similar to carrageenan and polysaccharide of $P$. pavonica shows similarity to alginate possessing varying biological activities. Higher DPPH activity and reducing power were recorded in the polysaccharide

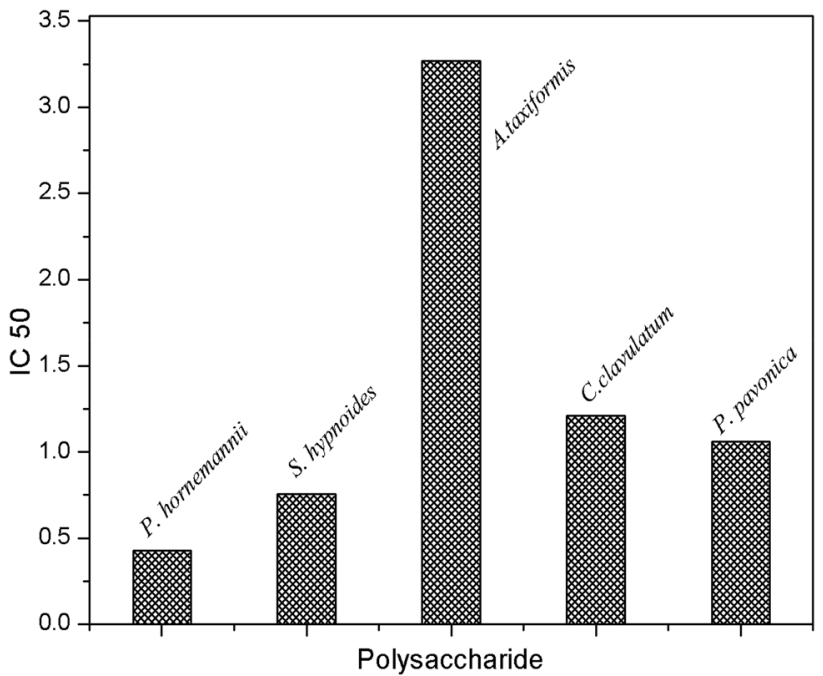

Fig. 7 IC50 value of cell survivability of different concentrations of polysaccharides (Portieria hornemannii-Ph, Spyridia hypnoides-Sh, Asparagopsis taxiformis-At, Centroceras clavulatum-Cc and Padina pavonica-Pp) tested by MTT Assay using HeLa cell line 
of brown $P$. pavonica than red seaweeds. Thus, the study clearly suggest that low molecular weight carrageenan like polysaccharide extracted from $P$. hornemannii, agar like from $S$. hypnoides and alginate polymer from $P$. pavonica shows in vitro antioxidant activities which are capable of inhibiting HeLa cell line could be used for biomedical applications whereas polysaccharides of $C$. clavulatum and $A$. taxiformis for nutraceutical products.

Acknowledgements The corresponding author Dr.R.Raja, sincerely acknowledges the University of Algarve, Faro for funding the researcher under the rule DL 57/2016, Portugal.

\section{References}

1. J. Guangling, Y. Guangli, Z. Junzeng, H.E. Stephen, Mar. Drugs. 9(2), 196-223 (2011)

2. P. Seema, Biotechnology 2(3), 171-185 (2012)

3. P.S. Kwon, S.J. Kwon, J. Weihua, Z. Fuming, F. Keith, Cell Discov. (Online) (2020)

4. N.-H. Ngo, K. Se-Kwon, Int. J. Biol. Macromol. 62, 70-75 (2013)

5. R. Raja, S. Hemaiswarya, K. Arunkumar, I.-S. Carvalho, Braz. J. Bot. 39(1), 9-17 (2016)

6. K.K. Sanjeewa, L. Asanka, K. Nalae, A. Ginnae, J. Youngheun, K. Young-Tae, L. You-Jin, Food Hydrocoll. 81, 200-208 (2018)

7. L. Pereira, S.F. Gheda, J. Paulo, A. Ribeiro-Claro, Int. J. Carbohydr. Chem. 537202, 7 (2013)

8. Q. Zhong, B. Wei, S. Wang, S. Ke, J. Chen, H. Zhang, H. Wang, Mar. Drugs 17(12), 674 (2019)

9. L.N. Panlasigui, O.Q. Baello, J.M. Dimatangal, B.D. Dumelod, Asia Pac. J. Clin. Nutr. 12, 209-214 (2003)

10. V.D. Prajapati, P.M. Maheriya, G.K. Jani et al., Carbohydr. Polym. 105, 97-112 (2014)

11. R. Pangestuti, S.-K. Kim, Adv. Food Nutr. Res. 72, 113-124 (2014)

12. R.W. Fuller, J.H. Cardellina, Y. Kato, L.S. Brinen, J. Clardy, K.M. Snader, M.R. Boyd, J. Med. Chem. 35, 3007-3011 (1992)

13. P.V. Neethu, K. Suthindhiran, M.A. Jayasri, Pharmacogn. Res, 9(3), 238-246 (2017)

14. M. Fabio, D.C. Gianfranco, C. Gugliandolo, S. Antonio, F. Caterina, G. Giuseppa, M. Marina, R. Annamaria, B. Davide, F. Francesco, S. Andrea, Front. Physiol. 7, 459 (2016)

15. N.M. Al-Enazi, A.S. Awaad, E.Z. Mohamed, S.I. Alqasoumi, Saudi Pharm. J. 26(1), 44-52 (2018)

16. G. Bernardini, M. Mariagiulia, P. Giuseppe, B. Manuele, S. Annalisa, Mar. Drugs 16, 504 (2018)

17. S. Distantina, A. Wiratni, M. Fahrurrozi, L. Rochmadi, World Acad. Sci. Eng. Technol. 78, 738-742 (2011)

18. A.G. Lloyd, K.S. Dodgson, R.G. Price, F.A.I. Rose, Biochem. Biophys. Acta 1, 108-115 (1961)

19. B.W. Souza, M.A. Cerqueira, A.I. Bourbon, A.C. Pinheiro, J.T. Martins, J.A. Teixeira, A.A. Vicente, Food Hydrocoll. 27(2), 287-292 (2012)

20. G.C. Yen, H.Y. Chen, J. Agric. Food Chem. 43, 27-32 (1995)

21. T. Mosmann, J. Immunol. Methods 65, 55-63 (1983)

22. S. Istini, M. Ohno, H. Kusunose, Bull. Mar. Sci. Fish. Kochi Univ. 14, 49-55 (1994)

23. D.J. Mc Hugh, Hydrobiology 221, 19-29 (1991)

24. E. Marinho-Soriano, E. Bourret, Biores. Technol. 96(3), 379-382 (2005)
25. L. Pereira, A.T. Critchley, A.M. Amado, P.J.A. Ribeiro-Claro, J. Appl. Phycol. 21, 599-605 (2009)

26. M.L. Weiner, D. Nuber, W.R. Blakemore, J.F. Harriman, S.M. Cohen, Food Chem. Toxicol. 45(1), 98-106 (2007)

27. B. Tanna, A. Mishra, Comp. Rev Food Sci. Food Saf. 18(3), 817-831 (2019)

28. L.S. Costa, G.P. Fidelis, S.L. Cordeiro, R.M.D.A. Oliveira, R. Sabry, B.G. Câmara, L.B. Nobre, M.P. Costa, J. Almeida-Lima, E.C. Farias, E.L. Leite, H.O. Rocha, Biomed. Pharmacol. 64(1), 21-28 (2010)

29. S. Yu-Fong, Y. Hui-Chun, L. Yen, Int. J. App. Sci. Eng. 7(1), 25-41 (2009)

30. A. Al-Alawi, P. Chitra, A. Al-Mamun, I. Al-Marhubi, M.S. Rahman, Int. J. Food Eng. 14, 20170353 (2018)

31. P. Zou, X. Lu, C. Jing, Y. Yuan, Y. Lu, C. Zhang, L. Meng, H. Zhao, Y. Li, Front Plant Sci. 9, 427 (2018)

32. M. Ghanbarzadeh, A. Golmoradizadeh, A. Homaei, Phytochem. Rev. 17, 535-571 (2018)

33. A.A. Kalitnik, A.O.B. Barabanova, V.P. Nagorskaya, A.V. Reunov, V.P. Glazunov, T.F. Solov'eva, I.M. Yermak, J Appl. Phycol. 25, 65-72 (2013)

34. S. Sudharsan, S. Giji, P. Seedevi, S. Vairamani, A. Shanmugam, Int. J. Biol. Macromol. 109, 589-597 (2018)

35. A. Manilal, S. Sujith, J. Selvin, M.V. Nataraja Panikkar, S. George, Thalassas Int. J. Mar. Sci. 28(2), 9-15 (2012)

36. D. Guo, Y. Kai, S. Xin-Yuan, O. Jian-Ming, Biological efficacy of medicinal plant extracts in preventing oxidative damage. Oxid. Med. Cell. Longev. 15, 1 (2018). https://doi. org/10.1155/2018/7904349

37. E. Fourest, B. Volesky, Appl. Biochem. Biotechnol. 67, 215-226 (1997)

38. C.K. Larsen, O. Gåserød, O. Smidsrød, Carbohydr. Polym. 51, 125-134 (2003)

39. M. Sen, E.N. Erboz, Food Res. Int. 43, 1361-1364 (2010)

40. E. Fourest, B. Volesky, Environ. Sci. Technol. 30(1), 277-282 (1996)

41. M. Xing, Q. Cao, Y. Wang et al., Mar. Drugs. 18(3), 144 (2020)

42. L.N. Callahan, M. Phelan, M. Mallinson, M.A. Norcross, J. Virol. 65, 1543-1550 (1991)

43. Z. Mellouk, I. Benammar, D. Krouf, M. Goudjil, M. Okbi, W. Malaisse, Exp. Ther. Med. 13(6), 3281-3290 (2017)

44. H. Jinzhe, Y. Xu, H. Chen, P. Sun, Int. J. Mol. Sci. 17(12), E1988 (2016)

45. J. Trinchero, M. Nora, M.A. Ponce, O.L. Córdoba, M. Lujan Flores, Phytother. Res. 23(5), 707-712 (2009)

46. L.B. Talarico, E.B. Damonte, Virology 363, 473-485 (2007)

47. S.T. Moe, K.I. Draget, G. Skjak-Brack, O. Smidsrod, Alginates, ed. (New York, USA, 1995), pp. 245-286

48. J. Craigie, (Cambridge University Press, Cambridge, UK, 1990), pp. 221-257

49. V. Jagatheesan, B.K. Pramanik, J. Chen et al., Biores. Technol. 204, 202-212 (2016)

50. D. Christiaen, M. Bodard, Bot. Mar. 26, 425-427 (1983)

51. M. Lahaye, Cah. Biol. Mar. 42, 137-157 (2001)

52. J. Wilma, A. Limewood, R. North Hamptonshire NN9 6NG (UK, 1990), pp. 53-60

53. I.P.S. Fernando, A. Sanjeewa, K.W. Samarakoon, W.W. Lee, H.-S. Kim, E.-A. Kim, D.K.S. Gunasekara, D.T.U. Abeytunga, C. Nanayakkara, E.D. Silva, H.-S. Lee, Y.-J. Jeon, Algae 32(1), 75-86 (2017)

54. T. Chopin, B.F. Kerin, R. Mazerolle, Phycol. Res. 47, 167-188 (1999)

55. D.M. Abid, L. Sirine, H.A. Hiba, C. Dora, E. Nejeh, M. Hatem, B. Abderrahman, Trends. Appl. Sci. Res. 4(2), 62-67 (2019)

56. R.M. Amir, F.M. Anjum, M.I. Khan, M.R. Khan, I. Pasha, M. Nadeem, J. Food Sci Technol. 50(5), 1018-1023 (2013) 
57. N.P. Chandía, B. Matsuhiro, E. Mejías, A. Moenne, J. Appl. Phycol. 16, 127-133 (2004)

58. S. Castro, J. de Paula Lima, L. Costa, L. Eduardo Castanheira, P.M.P. Francisco, T. dos Santos, P.H. de Menezes, F.L. Mistrello, D.R. Moschini, S.G. dos Ramalho Cardoso, C.N. Sérgio Medeiros, F.A. Lúcia Ponte, Polímeros 28(2), 178-186 (2018)

59. C.M.P.G. Dore, C. Faustino Alves, M.G.E.P. Will et al., Carbohydr. Polym. 91, 467-475 (2013)

60. N. Khaled, M. Hiba, C. Asma, Adv. Environ. Biol. 6, 42-48 (2012)

61. M.A.-E. Nouf, S.A. Amani, E.Z. Mohamed, I.A. Saleh, Saudi Pharm. J. 26(1), 44-52 (2018)

62. T. Ghosh, K. Chattopadhyay, M. Marschall, P. Karmakar, P. Mandal, B. Ray, Glycobiology 19, 2-15 (2009)

63. A. Rodrigo, N. Santos, R.J.A. Gurgel, H. Márjory Lima, Q. Ana Luíza Gomes, P. Regina Célia Monteiro, M. Vânia Maria Maciel, B.N. Maria Barros, Braz. Arch. Biol. Tech. 55(2), 171-181 (2012)
64. P. Seedevi, M. Moovendhan, S. Viramani, A. Shanmugam, Carbohydr. Polym. 155, 516-524 (2017)

65. M.D. Alshaikheid, A. Abdelhamid, A. Bouraoui, J. Adv. Res. Biotech. 4(1), 1-6 (2019)

66. R.M. El-Shazoly, M.A. Fawzy, Egypt Eur. J. Biol. Res. 8(4), 232-242 (2018)

67. L. Ktari, M. Guyot, J. App. Phycol. 11, 511-513 (1999)

68. E. Taskin, Z. Caki, M. Ozturk, E. Taskin, African. J. Biotechnol. 27, 4272-4277 (2010)

Publisher's Note Springer Nature remains neutral with regard to jurisdictional claims in published maps and institutional affiliations. 